NISTIR 7869

\title{
Interlaboratory Comparison Study to Support the Deepwater Horizon Natural Resource Damage Assessment: Description and Results for QA11Blood01- PAHs, PAH Metabolites, and DOSS in Solution and Blood
}

John R. Kucklick

Michele M. Schantz

http://dx.doi.org/10.6028/NIST.IR.7869

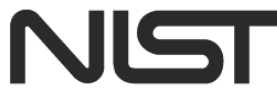

National Institute of Standards and Technology

U.S. Department of Commerce 
NISTIR 7869

\section{Interlaboratory Comparison Study to Support the Deepwater Horizon Natural Resource Damage Assessment: Description and Results for QA11Blood01- PAHs, PAH Metabolites, and DOSS in Solution and Blood}




\section{ABSTRACT}

To support natural resource damage assessment (NRDA) in response to the Deepwater Horizon (DWH) oil spill in the Gulf of Mexico, a large number of samples were collected from protected species including marine mammals and sea turtles. Analysis of these samples will continue for the foreseeable future. To support NRDA sample analyses, NOAA will require analytical laboratories in addition to the commercial laboratories that are currently listed as providing support to NRDA. To compare the data among these laboratories, interlaboratory comparison studies have been initiated, and the results from the fourth exercise, QA11Blood01, are reported here. In this exercise, selected polycyclic aromatic hydrocarbons (PAHs), alkylated PAHs, hydroxylated PAH metabolites and dioctyl sodium sulfosuccinate (DOSS) were determined in the exercise material, which consisted of a whole blood and plasma collected from American alligators (Alligator mississippiensis) amended with the test compounds. A solution containing known amounts of the test compounds was also distributed to help gauge analyses conducted on a matrix-free sample. The results from this fourth exercise are reported along with a summary of the analytical methods used.

\section{INTRODUCTION}

The National Institute of Standards and Technology (NIST) has conducted three interlaboratory comparison exercises to support the natural resource damage assessment (NRDA) in response to the Deepwater Horizon (DWH) oil spill in the Gulf of Mexico with marine sediment [1], crude oil [2], and mussel tissue [3] as the matrices of interest. The exercises were initiated to provide information on the comparability of data from different laboratories for PAHs (polycyclic aromatic hydrocarbons), alkylated PAHs, and petroleum biomarkers (hopanes and steranes). A large number of coastal sediment and tissue samples (e.g., oysters) have been collected outside of the spill zone to define baseline environmental conditions prior to being exposed to oil. For the foreseeable future, subsequent analysis of oiled sediments and oil-exposed oysters will be required as well. To support these efforts, additional analytical laboratories are being used to provide greater capacity for the NRDA evaluation.

The present exercise was designed to evaluate measurements of wildlife blood for selected PAHs, alkylated PAHs, hydroxylated PAH metabolites, and dioctyl sodium sulfosuccinate (DOSS). Blood was a matrix of interest for NRDA as this tissue was commonly collected from wildlife for assessment of hydrocarbon exposure. The study was performance-based; hence, laboratories were free to use the methods of their choosing. It is important to note that this exercise was not designed nor intended to reflect method performance for past results reported by the laboratories but rather to provide the laboratories the opportunity to assess methods of interest. The analytes chosen for this study were those commonly found in oil and/or used for source apportionment studies, or are metabolites of aromatic hydrocarbon exposure.

The data received from six laboratories for the exercise are summarized in this report along with summaries of the analytical methods used by each laboratory. For this exercise, laboratory performance was based on $\mathrm{p}$-scores that help gauge laboratory precision. Due to 
the small number of laboratories participating, z-scores, which are indicative of agreement to a consensus value, were not calculated. Among laboratory agreement is thus shown graphically.

\section{SOURCE OF MATERIAL}

There were four materials sent out to participants (Table 1): (1) a mixture of the PAH-related compounds in isooctane, (2) DOSS in methanol, (3) the target compounds added to pooled alligator plasma, and (4) the target compounds added to pooled alligator whole blood. The compounds used to prepare the samples above were purchased in either neat form or solution from Accustandard (New Haven, CT), Chiron (Trondheim, Norway) or Sigma (St. Louis, MO). Individual stock solutions of compounds were used to prepare a mixed spiking solution in ethanol that was added to the blood materials, a mixed PAH solution in isooctane, and a DOSS solution in methanol. Alligator plasma and whole blood were pooled from wild alligators, which were sampled during capture-release health assessments, and captive alligators. The blood (approximately $275 \mathrm{~g}$ of plasma or whole blood) was added to a $500 \mathrm{~mL}$ Erlenmeyer flask, spiked with approximately $0.8 \mathrm{~g}$ of the mixed analyte spiking solution, and stirred for 4 hours in the dark before aliquotting into $4.5 \mathrm{~mL}$ cryovials. Cryovials were then immediately frozen at -80 ${ }^{\circ} \mathrm{C}$.

Table 1: Summary of samples and target compounds added to the QA11blood01 materials. Blood material values are $\mathrm{pg} / \mathrm{g}$ while solution is $\mathrm{ng} / \mathrm{g}$.

\begin{tabular}{lcccc} 
& & & Material \\
Compound & QA11Plasma & QA11WholeBlood & QA11Solution\#1-PAH & QA11Solution\#2-DOSS \\
\hline Fluorene & 5007 & 5029 & 16.6 \\
Phenanthrene & 2925 & 2938 & 9.06 \\
Pyrene & 1992 & 2001 & 6.17 \\
Benzo[a]pyrene & 1745 & 1752 & 5.34 \\
2 methylnaphthalene & 21387 & 21480 & 68.8 \\
2,6-dimethyl naphthalene & 8516 & 8553 & 26.5 \\
1,7-dimethylphenanthrene & 543 & 546 & 1.71 \\
9-methylphenanthrene & 1982 & 1990 & 6.11 \\
3-methylphenanathrene & 4785 & 4806 & 14.8 \\
1-naphthol & 1644 & 1651 & 5.04 \\
2,3-dihydroxynaphthalene & 7220 & 7252 & 22.1 \\
2-methyl-1-naphthol & 337 & 338 & 1.13 \\
2-hyrdoxyfluorene & 5320 & 5343 & 16.5 \\
1-hydroxypyrene & 846 & 850 & 2.67 \\
Dioctylsodium succinate (DOSS) & 29965 & 30095 & \\
\hline
\end{tabular}




\section{SAMPLE DISTRIBUTION}

Four cryovials of QA11Plasma or QA11WholeBlood each containing $4 \mathrm{~mL}$ of frozen material were sent to seven laboratories the week of October 10, 2011. Each laboratory was requested to analyze three samples of each blood material and three measurements of QA11Solution\#1PAH and QA11Solution\#2-DOSS with their laboratory's and/or program's current analytical protocols being used for the determination of the concentrations (mass/mass) of the parent $\mathrm{PAH}$ compounds, alkylated PAH compounds, hydroxylated PAH compounds and DOSS.

The instructions including the list of target analytes sent to participants are given in Appendix A.

\section{EVALUATION OF EXERCISE RESULTS}

\section{Establishment of the Assigned Values}

Laboratory data submission: Each participating laboratory was asked to submit data from three replicate determinations of the "unknown" material QA11Plasma and QA11WholeBlood and was requested to report results of concurrent analyses of QA11Solution\#1-PAH and QA11Solution\#2-DOSS. The solution materials were used because NIST does not have a reference material for PAHs in blood, and the solutions provided information on laboratory measurements made on a matrix-free sample. Laboratories were requested to report these results to at least three significant figures and to provide brief descriptions of their cleanup and analytical procedures.

Determination of laboratory analyte means: For each laboratory, the laboratory analyte mean of the three sample results (S1, S2, and S3) was calculated for each analyte. Non-numerical data were treated as follows: A mean "<value" was used when three "<values" were reported; NA (not analyzed/determined) was used for three reported NAs; and, if the reported results were of mixed type, e.g., S1 and S2 were numerical values and S3 was reported as "<value", the two similar "types" were used to either determine the mean or to set a non-numerical descriptor.

Determination of assigned values: In prior exercises, the inclusion of a laboratory's data in the consensus value was based on their performance on the reference material. If values were within $30 \%$ of the assigned value for the reference material, their measurements on the unknown were included in the calculation of the consensus value for the unknown. This approach was not possible in the present exercise as there was no reference material included in the exercises. Consequently, the consensus values for this exercise are simply the median of all values submitted by all laboratories. No values were excluded due to the small number of laboratories submitting data. 


\section{REPORTED RESULTS}

Laboratories were assigned numerical identification codes in order of receipt of their data with the exception of the two NIST data sets, which are designated Laboratory 1 and 2 . The laboratory mean replicate data are shown in Tables 2, 3 and 4 for QA11Solution\#1-PAH and QA11Solution\#2-DOSS, QA11Plasma, and QA11Wholeblood, respectively. Included in the tables are the by-compound mean and standard deviation for the three measurements made on each matrix by each laboratory and the exercise assigned median values plus standard deviation. The gravimetric concentration that was based on the original weighing of the target compounds to make the exercise materials is also provided. Summaries of the methods used by each laboratory are in Appendix B. A second set of plasma and whole blood samples was distributed to laboratory 5 in February 2012 for an additional DOSS determination. Laboratory 5 therefore has two sets of DOSS values, those from the initial determination in 2011 and from the second set of samples analyzed in 2012.

\section{Performance Scores}

The exercise coordinators recognize that different environmental monitoring programs have different data quality objectives and needs. The acceptability of the results submitted by a particular laboratory will be decided by the individual program(s) for which the laboratory provides data. Typically, each program will use these exercise results in conjunction with the laboratory's performance in the analysis of certified reference materials and/or control materials, and of other quality assurance samples. These exercise results are exhibited in a number of ways in this report to facilitate their use by most environmental monitoring programs in their acceptability assessments.

\section{Precision Assessment (p-score)}

$$
\mathrm{p} \text {-score }=\sigma_{\text {lab }} / \sigma_{\text {target }}
$$

For the calculation of p-scores [4-5] for this program, the $\sigma$ values used are coefficients of variation (CV calculated as relative standard deviations) with the current target $\sigma(\mathrm{CV})$ for the three replicates being $15 \%$. The value of $15 \%$ was chosen for use interlaboratory comparison exercises of this type run by NIST. P-scores are only available for analytes where three measurements were made by the laboratory. Tables 2 through 4 summarize the relative standard deviations (RSDs) calculated from the three concentrations reported by the laboratory for each analyte quantified. Table 5 gives the $p$-scores (15\%). A p-score of 1 indicates that the laboratory's CV was $15 \%$, and a p-score of 2 indicates that the laboratory's CV was $30 \%$. 


\section{RESULTS and DISCUSSION}

NOAA's NRDA office requested that NIST coordinate an interlaboratory comparison exercise for PAHs, PAH metabolites, and DOSS in blood as this tissue had been collected from several wildlife species following the spill. With the help of NOAA and NRDA, NIST requested that five laboratories outside of NIST participate in an interlaboratory comparison exercise using bloodbased samples. Of these five laboratories, four submitted data sets with two additional data sets submitted by NIST. Laboratory 5 submitted two data sets for DOSS (see above). The listing of participating laboratories is given in Appendix C.

Tables 2 through 4 summarize the laboratory means and exercise assigned values for the PAHs, alkylated PAHs, hydroxylated PAHs and DOSS in the solution, plasma, and whole blood materials, respectively. The consensus values for the materials were simply the median concentrations of the submitted results. Given the small number of values reported, no data were excluded from the derivation of the consensus value. The gravimetric values are given in the tables for guidance. For most compounds, the gravimetric value was within the range of data reported back by the laboratories especially for the solution material. This was also true for the blood materials with the exception of the methylnaphthalenes that had higher gravimetric values than the reported values. The most likely explanation for this discrepancy is that the methylnaphthalenes that were added to the blood were partially lost through evaporation at some point in the preparation of the blood materials. There were few reported values for the hydroxylated PAHs so it is difficult to gauge the accuracy of the gravimetric values relative to these compounds. Prior experience with hydroxylated compounds has shown that concentrations can change in solution either through degradation, conjugation, or possibly sorption to container walls. DOSS was measured by three laboratories (Labs 3, 5, and 6). The median of measured values for DOSS agreed very well with the gravimetric concentration (Tables 2-4). The CV for the three labs was higher for DOSS in the blood materials (ca. $40 \%$ ) than for the solution (ca. $5 \%$ ).

As expected, the agreement among laboratories for the compounds in the matrix-free solution was better than that observed in the blood materials. The coefficients of variation (standard deviation/median) were $17 \%, 53 \%$, and $70 \%$ for the solution, plasma, and whole blood, respectively. Excluding the high fluorene and pyrene values reported by Lab 6 reduced the CVs to $33 \%$ for plasma and $48 \%$ for whole blood. This indicates that reported values in plasma are less variable among laboratories than those made on whole blood. This result is reasonable as the plasma is largely free of cellular material relative to whole blood and therefore should be less subject to matrix effects during analysis.

The precision or " $\mathrm{p}$ " scores, which are a measure of within laboratory repeatability, are given in Table 5. Again, a p-score of $\leq 1$ indicates that a laboratory's reported values are within $15 \%$ of their mean reported value. P-scores were only calculated on the blood materials and were generally $<0.5$ for most analytes in most laboratories. 1,7-dimethylphenanthrene had a higher p-score than other compounds probably due to the low concentration of this compound relative to other compounds in the samples (Tables 2-4). 
The methods used to analyze the samples varied among laboratories (Appendix B Tables B1B7). Extraction methods for the PAHs included microwave extraction (Lab 1), liquid:liquid extraction (Labs 2, 4, and 5), and QuECHERS (Quick Easy Cheap Effective Rugged Safe, essentially liquid:liquid extraction with acetonitrile following the addition of salts; Labs 3 and 6). DOSS was extracted by QuECHERS (Labs 3 and 6) or by liquid:liquid extraction using acetonitrile (Lab 5). Cleanup of samples prior to PAH analysis included size exclusion followed by solid phase extraction (Labs 1, 3, and 4) and no cleanup (labs 2, 5, and 6). Prior experience in our laboratory has shown cleanup of blood extracts is required for the analysis of persistent organic pollutants by GC/MS [4], hence it was surprising that several laboratories opted for no cleanup. Labs did not clean up extracts prior to DOSS analysis. For the analysis of the parent PAHs, five laboratories used GC/MS with 5\% methylpolysiloxane-phase column (Labs 2 through 5) or a $50 \%$ methylpolysiloxane-phase column (Lab 1). Lab 6 used UPLC/FLR/MS/MS with a C18 column. For alkylated PAHs, all labs used GC/MS with columns noted in Table B5; although, Lab 6 used GC/MS/MS. All labs used LC/MS/MS for the analysis of DOSS. Hydroxylated PAHs were determined by Labs 1 and 2 using GC/MS following derivatization with MSTFA and Lab 6 performed the analysis by UPLC/FLR/MS/MS. Additional details are given in Appendix $B$.

In conclusion, results demonstrated that it is possible to measure a suite of parent and alkylated PAHs in blood with reasonable agreement among laboratories. The three laboratories that measured the oil dispersant compound, DOSS, were also able to provide a consensus value that was very close to the nominal concentration of DOSS in the samples (Tables 3 and 4). PAH metabolites were a challenge for laboratories with very few results being submitted by the group. While there are several methods for PAH metabolites in urine published in the literature, this is not the case for PAHs in blood which may explain the low number of values submitted by laboratories. Based on preliminary work done by NIST, hydroxylated PAHs also might not achieve stable concentrations when spiked in blood. Further studies are needed to determine the feasibility of providing a reference material for hydroxylated PAHs in blood and to provide reliable methods for hydroxylated $\mathrm{PAH}$ analysis in blood samples.

\section{Acknowledgments}

The time and effort of the analysts and management of the participating laboratories are gratefully acknowledged. We also gratefully acknowledge the laboratory of Dr. Louis Guillette, specifically Dr. Thomas Rainwater and Dr. Satomi Kohno, for supplying us with the alligator plasma and whole blood.

\section{Disclaimer}

Certain commercial equipment, instruments, or materials are identified in this report to specify adequately the experimental procedure. Such identification does not imply recommendation or endorsement by the National Institute of Standards and Technology, nor does it imply that the materials or equipment identified are the best available for the purpose. 


\section{References}

1. Schantz, M.M. and Kucklick, J.R., Interlaboratory Analytical Comparisons Study to Support Deepwater Horizon Natural Resource Damage Assessment: Description and Results for Marine Sediment QA10SED01, NISTIR 7792, Gaithersburg, MD (2011).

2. Schantz, M.M. and Kucklick, J.R., Interlaboratory Analytical Comparisons Study to Support Deepwater Horizon Natural Resource Damage Assessment: Description and Results for Crude Oil QA10OIL01, NISTIR 7793, Gaithersburg, MD (2011).

3. Schantz, M.M. and Kucklick, J.R., Interlaboratory Analytical Comparisons Study to Support Deepwater Horizon Natural Resource Damage Assessment: Description and Results for Mussel Tissue QA10TIS01, NISTIR 7819, Gaithersburg, MD (2011).

4. ISO/IEC 17043: 2010 Conformity Assessment-General Requirements for Proficiency Testing

5. IUPAC "The International Harmonized Protocol for the Proficiency Testing of (Chemical) Analytical Laboratories," Pure \& Appl. Chem., 65 (9), 2123-2144 (1993).

6. Keller JM, Swarthout RF, Carlson BK, Yordy J, Guichard A, Schantz MM, Kucklick JR. 2009. Comparison of five extraction methods for measuring PCBs, PBDEs, organochlorine pesticides, and lipid content in serum. Anal Bioanal Chem 393(2): 747-760. 
Table 2: Tabular results from the analysis of QA11Solution\#1-PAH and QA11Solution\#2-DOSS. All values are ng/g. Gravimetric refers to concentration expected based on the mass of compound added to the solution.

\begin{tabular}{|c|c|c|c|c|c|c|c|c|c|c|c|c|c|c|c|}
\hline \multirow[b]{3}{*}{ Compound } & \multicolumn{12}{|c|}{ Laboratory } & \multirow[b]{3}{*}{ median } & \multirow[b]{3}{*}{ SD } & \multirow[b]{3}{*}{ Gravimetric } \\
\hline & \multicolumn{2}{|c|}{1} & \multicolumn{2}{|c|}{2} & \multicolumn{2}{|c|}{3} & \multicolumn{2}{|c|}{4} & \multicolumn{2}{|c|}{5} & \multicolumn{2}{|c|}{6} & & & \\
\hline & mean & RSD (\%) & mean & RSD (\%) & mean & RSD (\%) & mean & RSD (\%) & mean & RSD (\%) & mean & RSD (\%) & & & \\
\hline fluorene & 15.9 & 2.0 & 16.7 & 7.4 & 14.4 & NA & 11.1 & 3.4 & 12.2 & 3.7 & 9.07 & 7.9 & 13.3 & 2.9 & 16.6 \\
\hline phenanthrene & 9.75 & 0.7 & 9.27 & 5.0 & 7.07 & NA & 8.08 & 1.7 & 7.35 & 3.8 & $<L O D$ & NA & 8.08 & 1.2 & 9.06 \\
\hline pyrene & 6.15 & 3.1 & 5.09 & 6.5 & 5.43 & NA & 5.24 & 12 & 5.05 & 5.1 & 7.61 & 5.6 & 5.33 & 1.0 & 6.17 \\
\hline benzo[a]pyrene & 4.75 & 3.7 & 6.86 & 9.0 & 4.51 & NA & 4.13 & 9.9 & 4.00 & 0.8 & 7.30 & 10 & 4.63 & 1.4 & 5.34 \\
\hline 1-methylnaphthalene & $<L O D$ & NA & NA & $<L O D$ & $<1.6$ & $<L O D$ & $<1.5$ & NA & NA & NA & NA & NA & & & \\
\hline 2-methylnaphthalene & 58.7 & 0.8 & 65.2 & 6.6 & 78.2 & NA & 62.9 & 2.4 & 50.5 & 2.6 & 55.1 & 4.6 & 60.8 & 9.6 & 68.8 \\
\hline 2,6-dimethylnaphthalene & 23.2 & 1.8 & 19.9 & 9.9 & 24.3 & NA & 22.6 & 8.6 & 20.6 & 6.7 & 24.4 & 2.8 & 22.9 & 1.9 & 26.5 \\
\hline 1,7-dimethylphenanthrene & 2.26 & 7.0 & 1.79 & 10 & 1.37 & NA & 2.07 & 13 & NA & NA & NA & NA & 1.93 & 0.4 & 1.71 \\
\hline 9-methylphenanthrene & 7.44 & 1.6 & 6.16 & 12 & 5.42 & NA & 5.26 & 2.2 & 4.81 & 2.6 & 5.52 & 1.5 & 5.47 & 0.9 & 6.11 \\
\hline 3-methylphenanthrene & 15.2 & 1.8 & 16.4 & 8.2 & 12.4 & NA & 11.6 & 7.4 & 12.1 & 5.6 & 14.9 & 10.6 & 13.7 & 2.0 & 14.8 \\
\hline 1-naphthol & $<L O D$ & NA & 6.86 & 9.0 & NA & NA & NA & NA & NA & NA & 5.14 & 4.4 & 6.00 & & 5.04 \\
\hline 2,3-dihydroxynaphthalene & $<L O D$ & NA & $<1$ & NA & NA & NA & NA & NA & NA & NA & $<L O D$ & NA & & & 22.1 \\
\hline 2-methyl-1-naphthol & $<L O D$ & NA & $<1$ & NA & NA & NA & NA & NA & NA & NA & $<L O D$ & NA & & & 1.13 \\
\hline 2-hydroxyfluorene & 7.80 & 2.3 & NA & NA & NA & NA & NA & NA & NA & NA & 12.7 & 1.6 & 10.2 & & 16.5 \\
\hline 1-hydroxypyrene & 2.06 & 0.3 & other & NA & NA & NA & NA & NA & NA & NA & $<\mathrm{LOD}$ & NA & & & 2.67 \\
\hline DOSS (ion) & NA & NA & NA & NA & 116 & 1.0 & NA & NA & 110 & 7.7 & 121 & 1.3 & 116 & 5.7 & 110 \\
\hline
\end{tabular}


Table 3: Tabular results from the analysis of QA11Plasma. All values are pg/g. Gravimetric refers to concentration expected based on the mass of compound added to the blood.

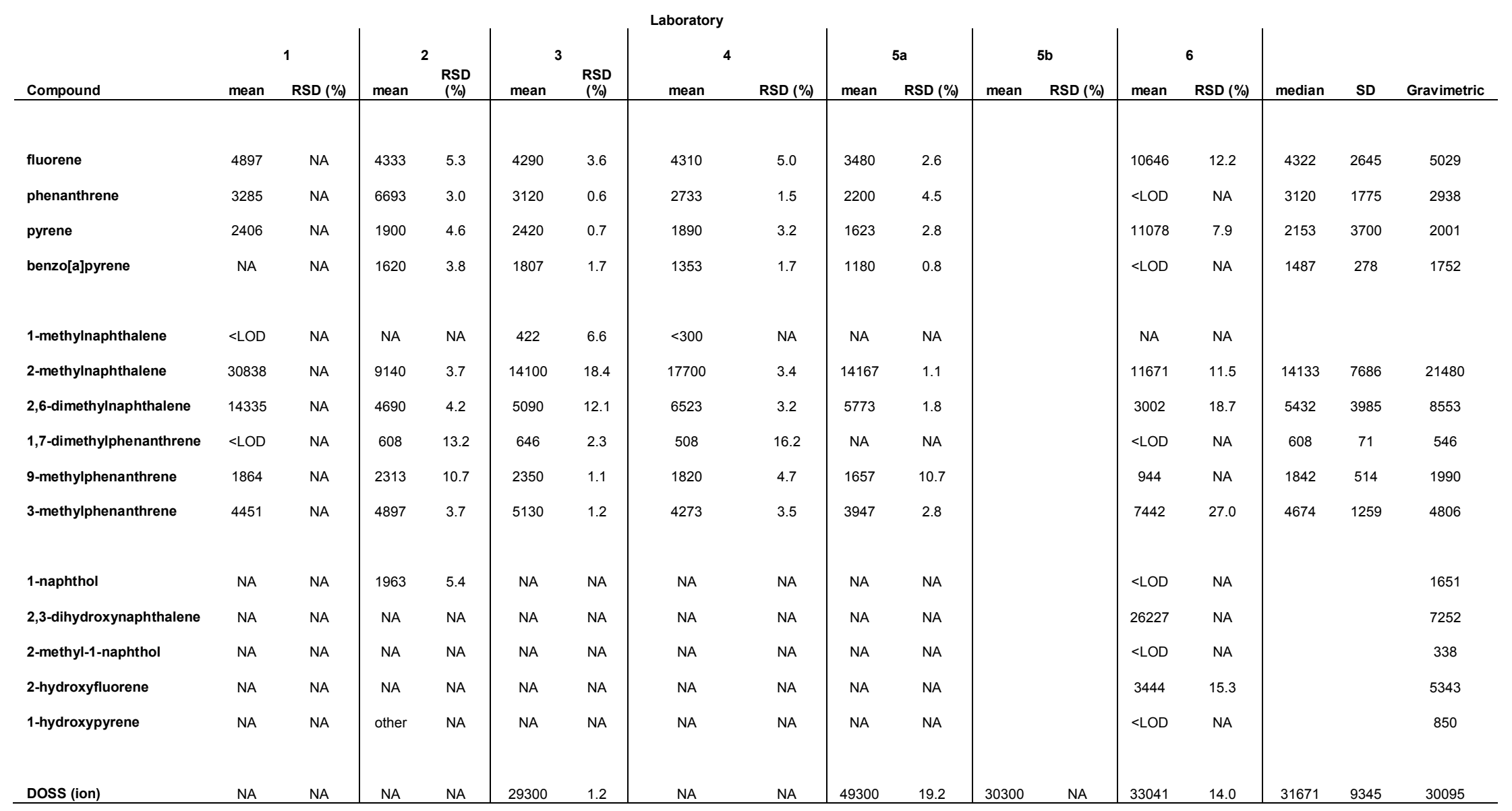


Table 4: Tabular results from the analysis of QA11WholeBlood. All values are $\mathrm{pg} / \mathrm{g}$. Gravimetric refers to concentration expected based on the mass of compound added to the blood.

\begin{tabular}{|c|c|c|c|c|c|c|c|c|c|c|c|c|c|c|c|c|c|}
\hline \multirow[b]{2}{*}{ Compound } & & 1 & & 2 & & 3 & Labor & 4 & & a & & b & \multicolumn{2}{|c|}{6} & \multirow[b]{2}{*}{ median } & \multirow[b]{2}{*}{ SD } & \multirow[b]{2}{*}{ Gravimetric } \\
\hline & mean & RSD (\%) & mean & RSD (\%) & mean & RSD (\%) & mean & RSD (\%) & mean & RSD (\%) & mean & RSD (\%) & mean & RSD (\%) & & & \\
\hline fluorene & 5178 & 5.6 & 4217 & 7.9 & 3030 & 4.0 & 1237 & 4.1 & 2333 & 1.6 & & & 12051 & 19.1 & 3623 & 3870 & 5007 \\
\hline phenanthrene & 3228 & 5.1 & 7723 & 3.5 & 3040 & 1.4 & 2517 & 13.2 & 2013 & 5.2 & & & $<L O D$ & NA & 3040 & 2296 & 2925 \\
\hline pyrene & 2285 & 7.4 & 1747 & 3.2 & 2367 & 2.2 & 1840 & 5.2 & 1447 & 6.9 & & & 11859 & 11.4 & 2063 & 4065 & 1992 \\
\hline benzo[a]pyrene & NA & NA & 1627 & 10.5 & 1123 & 12.7 & 678 & 10.3 & 555 & 17.1 & & & $<L O D$ & NA & 901 & 486 & 1745 \\
\hline 1-methylnaphthalene & $<L O D$ & NA & & & 356 & 4.2 & $<300$ & NA & NA & NA & & & NA & NA & & & \\
\hline 2-methylnaphthalene & 22377 & $\begin{array}{l}2.6 \\
\text { NA }\end{array}$ & $\begin{array}{l}9730 \\
\text { NA }\end{array}$ & 3.9 & 8390 & 12.8 & 15767 & 11 & 8720 & 74.1 & & & 5853 & 54.9 & 9225 & 6138 & 21387 \\
\hline 2,6-dimethylnaphthalene & 10286 & $3.9^{\mathrm{NA}}$ & 4620 & 8.4 & 4017 & 7.9 & 5860 & 14 & 5150 & 2.5 & & & 2167 & 21.3 & 4885 & 2724 & 8516 \\
\hline 1,7-dimethylphenanthrene & $<L O D$ & NA & 858 & 6.6 & 632 & 1.4 & 402 & 6.5 & NA & NA & & & NA & NA & 632 & 228 & 543 \\
\hline 9-methylphenanthrene & 1697 & 2.1 & 2473 & 5.9 & 2330 & 0.9 & 1663 & 7.2 & 1623 & 10.5 & & & 450 & NA & 1680 & 716 & 1982 \\
\hline 1-naphthol & NA & NA & 2100 & 5.7 & NA & NA & NA & NA & NA & NA & & & 10789 & NA & & & 1644 \\
\hline 2,3-dihydroxynaphthalene & NA & NA & NA & NA & NA & NA & NA & NA & NA & NA & & & $<L O D$ & NA & & & 7220 \\
\hline 2-methyl-1-naphthol & NA & NA & NA & NA & NA & NA & NA & NA & NA & NA & & & $<L O D$ & NA & & & 337 \\
\hline 2-hydroxyfluorene & NA & NA & NA & NA & NA & NA & NA & NA & NA & NA & & & $<L O D$ & NA & & & 5320 \\
\hline 1-hydroxypyrene & NA & NA & other & NA & NA & NA & NA & NA & NA & NA & & & $<L O D$ & NA & & & 846 \\
\hline Doss (ion) & NA & NA & NA & NA & 27567 & 3.7 & NA & NA & 55367 & 3.7 & 27200 & NA & 28236 & 3.6 & 27901 & 13856 & 29965 \\
\hline
\end{tabular}


Table 5: p scores based on a relative standard deviation of $15 \%$ for the blood materials.

$$
\text { Lab } 1 \quad \text { Lab } 2 \quad \text { Lab } 3 \quad \text { Lab } 4
$$

Lab $5 a$

Lab 6

plasma whole blood plasma whole blood plasma whole blood plasma whole blood plasma whole blood plasma whole blood

\begin{tabular}{|c|c|c|c|c|c|c|c|c|c|c|c|c|}
\hline fluorene & NA & 0.37 & 0.35 & 0.53 & 0.24 & 0.27 & 0.33 & 0.27 & 0.17 & 0.11 & 0.81 & 1.27 \\
\hline phenanthrene & NA & 0.34 & 0.20 & 0.23 & 0.04 & 0.10 & 0.10 & 0.88 & 0.30 & 0.35 & NA & NA \\
\hline pyrene & NA & 0.49 & 0.31 & 0.21 & 0.05 & 0.14 & 0.21 & 0.35 & 0.19 & 0.46 & 0.53 & 0.76 \\
\hline benzo[a]pyrene & NA & NA & 0.25 & 0.70 & 0.11 & 0.85 & 0.11 & 0.69 & 0.06 & 1.14 & NA & NA \\
\hline 1-methylnaphthalene & NA & NA & NA & NA & 0.44 & 0.28 & NA & NA & NA & NA & NA & NA \\
\hline 2-methylnaphthalene & NA & 0.58 & 0.25 & 0.26 & 1.23 & 0.85 & 0.23 & 0.72 & 0.07 & 4.94 & 0.77 & 3.66 \\
\hline 2,6-dimethylnaphthalene & NA & 0.62 & 0.28 & 0.56 & 0.81 & 0.53 & 0.22 & 0.95 & 0.12 & 0.17 & 1.24 & 1.42 \\
\hline 1,7-dimethylphenanthrene & NA & NA & 0.88 & 0.44 & 0.16 & 0.10 & 1.08 & 0.43 & NA & NA & NA & NA \\
\hline 9-methylphenanthrene & NA & 0.14 & 0.72 & 0.39 & 0.08 & 0.06 & 0.31 & 0.48 & 0.72 & 0.70 & NA & NA \\
\hline 3-methylphenanthrene & NA & 0.14 & 0.25 & 0.07 & 0.08 & 0.04 & 0.23 & 0.79 & 0.19 & 0.40 & 1.80 & 0.58 \\
\hline 1-naphthol & NA & NA & 0.36 & 0.38 & NA & NA & NA & NA & NA & NA & NA & NA \\
\hline 2,3-dihydroxynaphthalene & NA & NA & NA & NA & NA & NA & NA & NA & NA & NA & NA & NA \\
\hline 2-methyl-1-naphthol & NA & NA & NA & NA & NA & NA & NA & NA & NA & NA & NA & NA \\
\hline 2-hydroxyfluorene & NA & NA & NA & NA & NA & NA & NA & NA & NA & NA & 1.02 & NA \\
\hline 1-hydroxypyrene & NA & NA & NA & NA & NA & NA & NA & NA & NA & NA & NA & NA \\
\hline DOSS (ion) & NA & NA & NA & NA & 0.08 & 0.25 & NA & NA & 1.28 & 0.24 & 0.93 & 0.24 \\
\hline
\end{tabular}


Figures 1a and 1b: QA11Solution\#1-PAH. Consensus is the median of all values.

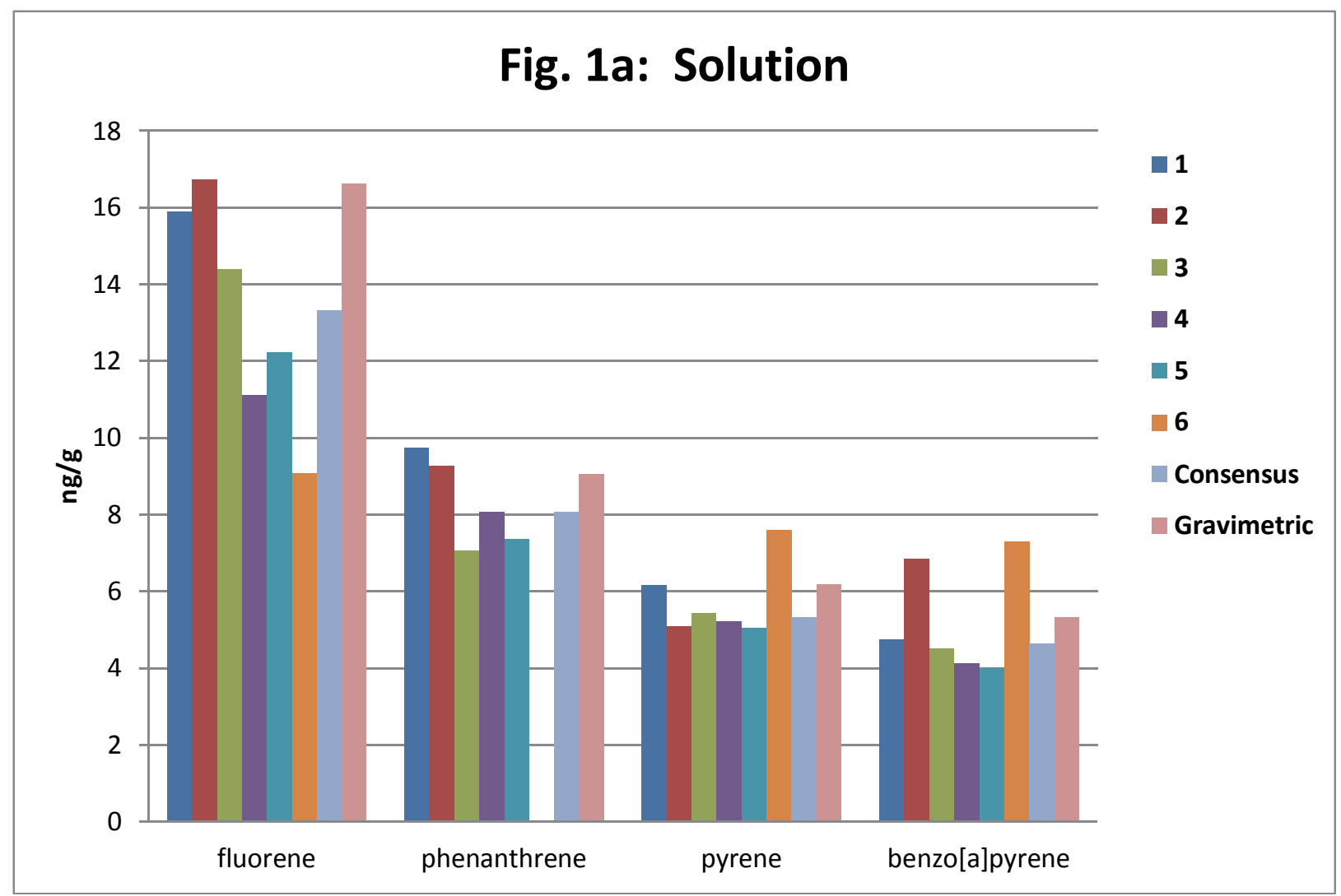


Fig. 1b: Solution

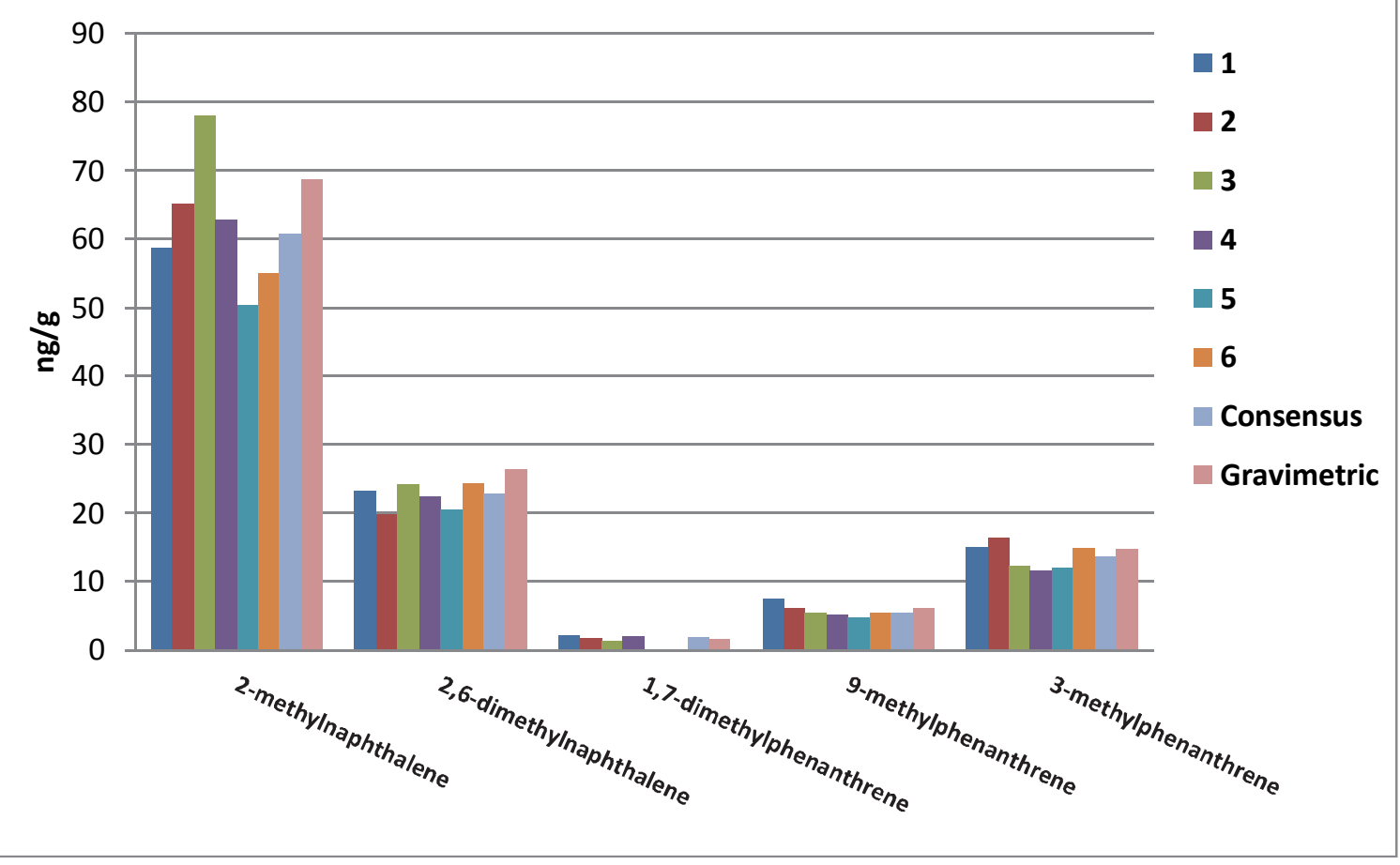


Figures 2a and 2b: Graphical results from QA11Plasma. Consensus is the median of all values.

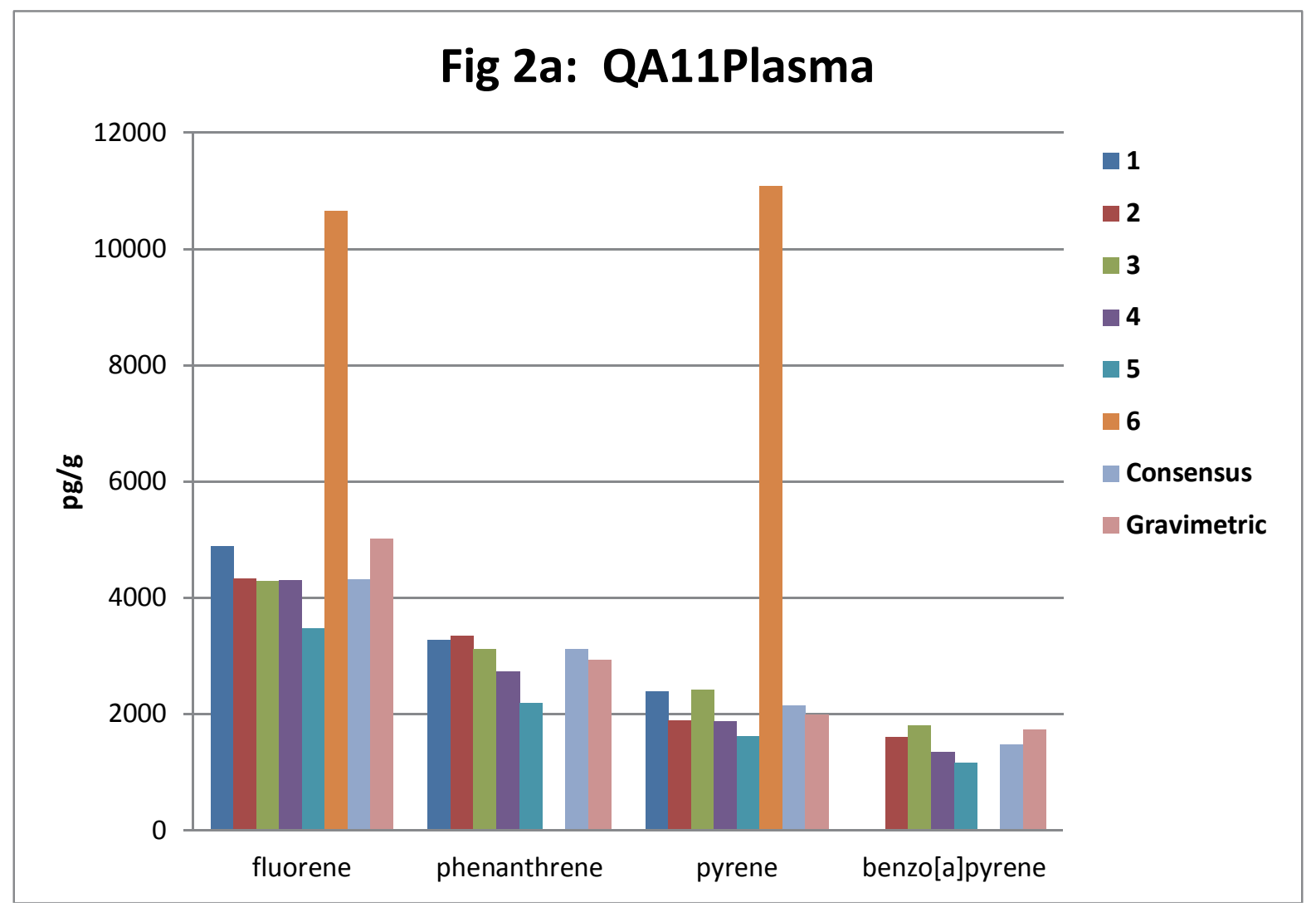


Fig. 2b: QA11Plasma

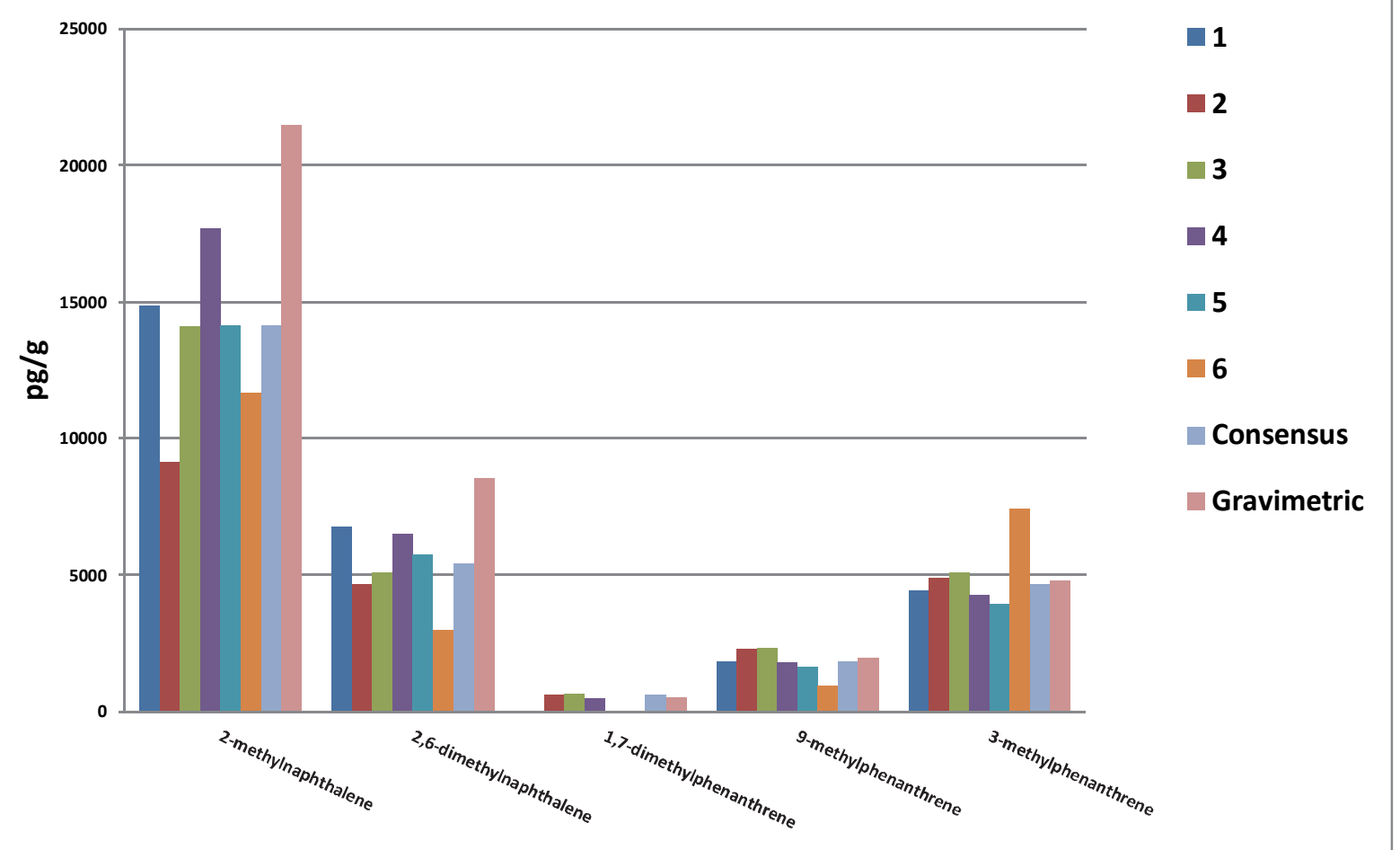


Figures 3a and 3b: Graphical results from QA11WholeBlood. Consensus is the median of all values.

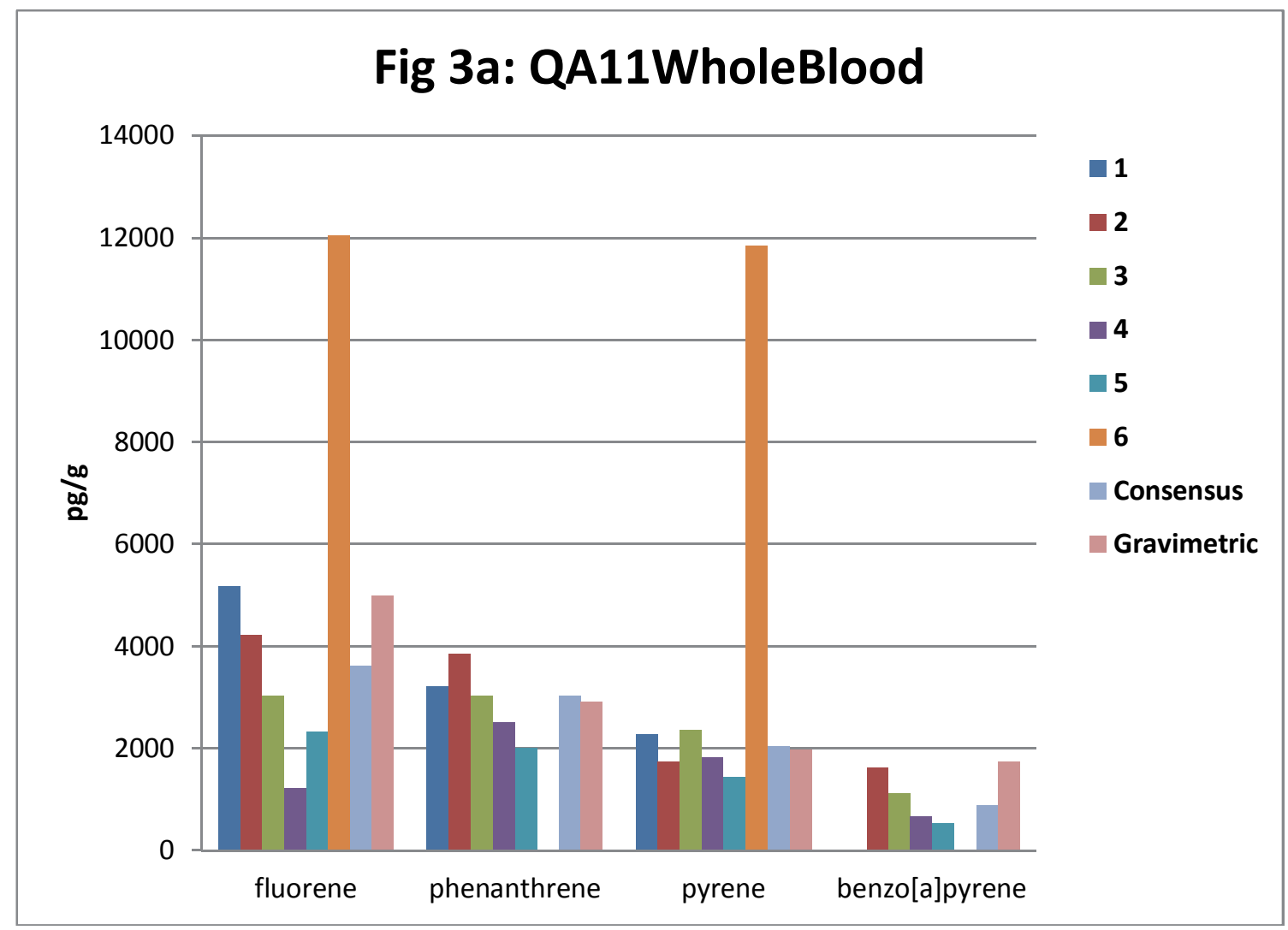


Fig 3b: QA11WholeBlood

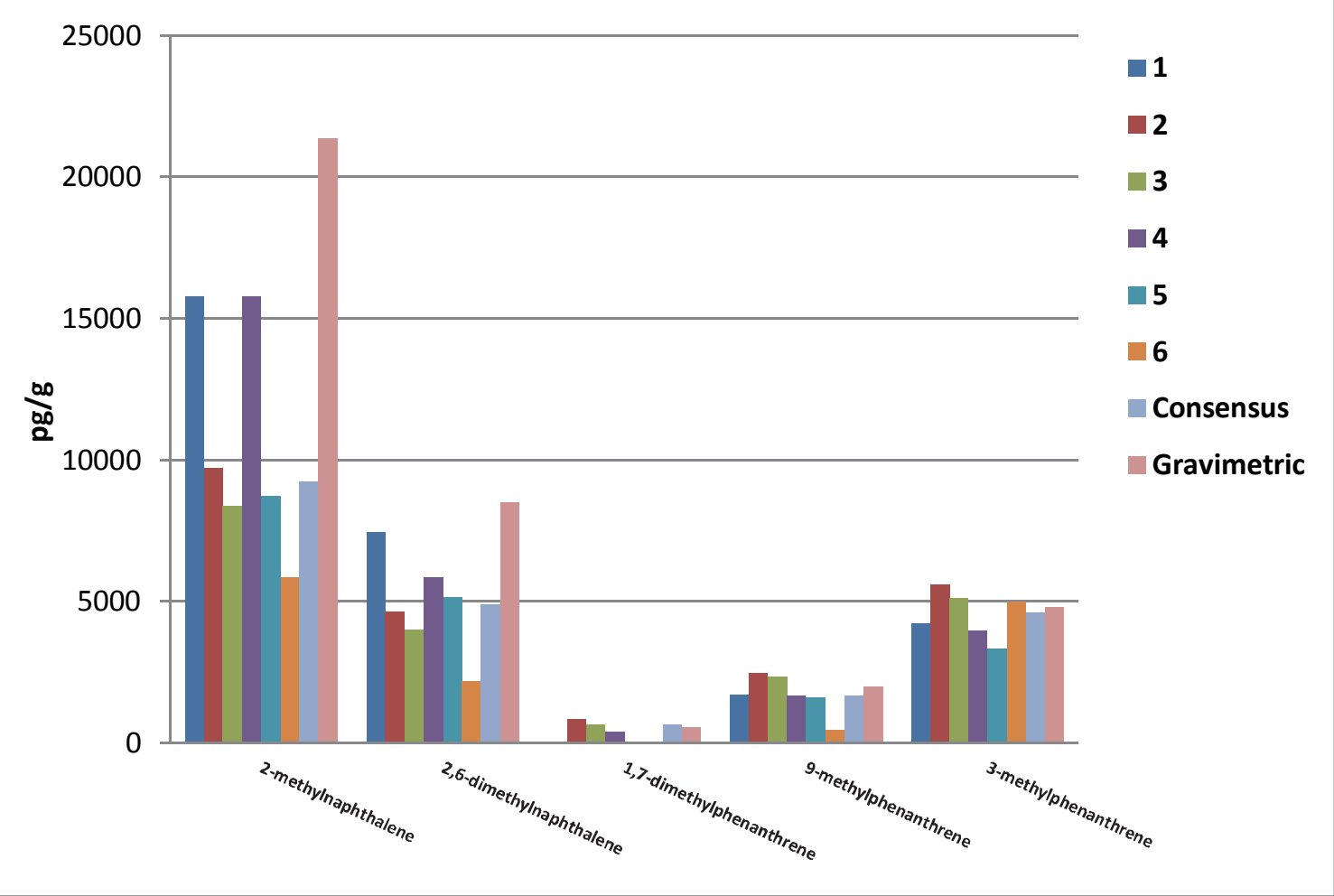


Appendix A: Instructions for the Exercise 


\section{Interlaboratory Analytical Comparison Study to Support Deepwater Horizon Natural Resource Damage Assessment}

\section{Intercomparison Exercise: Blood QA1101 Description of Materials and Instructions}

\section{Intercomparison Exercise Materials:}

There are three materials to be used for the exercise. The plasma and whole blood (QA11Plasma and QA11WholeBlood) samples are $4.5 \mathrm{~mL}$ aliquots of plasma and whole blood in collected non-lethally from American alligators. Both materials have been amended with the parent PAHs, alkylated PAHs and PAH metabolites listed in Table 1 and dioctyl sodium sulfosuccinate (DOSS). Concentrations range from $<1 \mathrm{ng} / \mathrm{mL}$ up to approximately $20 \mathrm{ng} / \mathrm{mL}$. Four vials per material are supplied; three are to be analyzed for the exercise and an extra vial is supplied as a backup.

Two additional solutions are also supplied. The first solution contains parent, alkylated PAHs and PAH metabolites in isooctane (QA11Solution\#1-PAH) and the second solution is DOSS in methanol (QA11Solution\#2-DOSS).

\section{Storage of Materials:}

The blood materials should be stored at a minimum of $-20{ }^{\circ} \mathrm{C}$ in the dark. Blood can be stored in a $-80^{\circ} \mathrm{C}$ freezer as well (preferred). The two solutions (QA11Solutions \#1 and \#2) should be stored between of $-4{ }^{\circ} \mathrm{C}$ and $-20{ }^{\circ} \mathrm{C}$ in the dark until use.

\section{Instructions for Use:}

You are to analyze all materials using your laboratory's and/or program's analytical protocols, for the concentrations (mass/mass) of the parent PAH compounds, alkylated PAH compounds, PAH metabolites and DOSS. A target list of compounds are presented in Table 1; however, participants do not need to quantify all of these compounds and can add additional compounds when reporting the data.

The amount of blood used for each analysis should correspond to the amount of blood that you would typically analyze as prescribed in your protocols. Prior to opening the blood cryovials you should vortex the vial to mix the contents. Samples for analysis should be withdrawn immediately after opening the cryovial and should be processed without delay. Unused material can be stored frozen in the cryovials.

The PAH and DOSS solutions (QA11Solutions \#1 and \#2) should be analyzed as is without cleanup. The mass of each vial (solution, cap and vial) was taken just prior to shipment. Weight each vial prior to use and use the supplied tare mass (vial plus cap) to adjust for solvent evaporation. 
You should analyze three samples of QA11Plasma and QA11WholeBlood and make three measurements each of the QA11Solution\#1-PAH and QA11Solution\#2-DOSS. If time allows, we are asking that you analyze the blood materials in separate batches; i.e., separate extractions, cleanup, and calibration curves. This will allow a more realistic assessment of laboratory precision over a longer term than the assessment obtained when a laboratory places all three samples in the same batch and the resulting extracts are analyzed using the same calibration curve, etc. Likewise, if time allows, make three separate measurements of QA11Solution\#1$\mathrm{PAH}$ and QA11Solutions\#2-DOSS using a separate calibration curve for each measurement.

\section{Reporting of Results:}

Please report one result, as if three figures were significant, for each of the analytes quantified in each of the three replicates of the QA11WholeBlood and QA11Plasma and the determination of compounds in QA11Solution\#1-PAH and QA11Solution\#2-DOSS. Report results in units of $\mathrm{pg} / \mathrm{g}$. Report the date of measurement of each sample in the requested $\mathrm{m} / \mathrm{d} / \mathrm{y}$ format.

If you know that a target or non-target compound is interfering (coeluting) with the determination of a target analyte, please identify this issue by qualifying the data and note the data qualifier used at the bottom of your table of results. Please note that any changes you make to the column or row headings within the tables will not be seen by the coordinators because only the table entries and comments at the bottom of the tables are automatically transferred to the exercise database.

We prefer that concentration values be reported for each analyte determined. If the measured concentration is below your typical reporting concentration for an analyte in a particular matrix, you can report the number and list the appropriate detection limit, quantification limit, etc. at the bottom of the data table. However, if you need to report non-numerical data please use the following conventions:

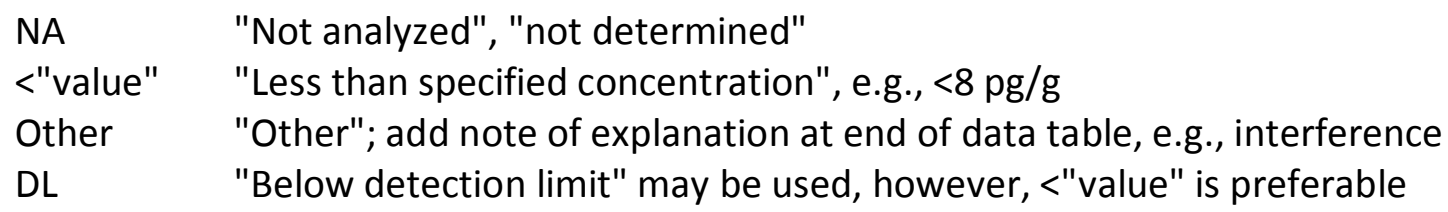

Do not use negative numbers or parentheses to indicate "less than detection limits".

The attached file is an EXCEL file, QA11Blood01.xls. If you have any software/hardware conversion problems, please contact John Kucklick. The data file templates also include places for you to list the surrogate/internal standards and type of calibration curve used, and to provide a brief description of the analyses. Please do not add spaces before entering numbers in the table cells and enter them as "numbers" not as "labels". Please do not insert any columns or rows within the table in the data file. If you wish to include additional data and/or other information or comments, you may add it to the bottom of the data table in the attached file. 
Submit your results by November 28, 2011 as an attached file via e-mail to: John.kucklick@nist.gov

Further Information:

If you need further information, please contact John at the following address or phone numbers:

John Kucklick

NIST/Hollings Marine Laboratory

331 Fort Johnson Road

Charleston, SC 29412

Phone:843-725-4816

Table 1: List of Analytes of Interest in the Interlaboratory Analytical Comparison Study to Support Deepwater Horizon Natural Resource Damage Assessment

\section{Parent PAHs:}

Benzo[a]pyrene

Fluorene

Pyrene

Phenanthrene

\section{Alkylated PAHs:}

2,6-dimethylnaphthalene

2-methylnaphthalene

1,7-dimethylphenanthrene

9-methylphenanthrene

3-methyl phenanthrene

\section{PAH Metabolites:}

2,3-dihydroxynaphthalene

1-naphthol

2-hyrdoxyfluorene

2-methyl-1-naphthol

1-hydroxypyrene

Oil Dispersant Indicator Compound:

dioctyl sodium sulfosuccinate (DOSS) 
Appendix B: Summary of Methods Used 
Table B1: Methods used for solutions.

\begin{tabular}{|c|c|c|c|c|c|c|}
\hline Lab \# & Instrument & Phase & PAHs & Mode of injection & $\begin{array}{c}\text { Calibration } \\
\text { curve \# } \\
\text { points }\end{array}$ & Range \\
\hline 1 & GC/MS & Rxi-17sil & $60 \mathrm{~m} \times 0.25 \mathrm{~mm} \times 0.25 \mu \mathrm{m}$ & PTV & 6 & $1600 \mathrm{ng} / \mathrm{mL}$ to $0.32 \mathrm{ng} / \mathrm{mL}$ \\
\hline 2 & GC/MS & HP5-MS & $30 \mathrm{~m} \times 0.25 \mathrm{~mm} \times 0.25 \mu \mathrm{m}$ & splitless & 4 & $0.5 \mathrm{ng} / \mathrm{g}$ to $160 \mathrm{ng} / \mathrm{g}$ \\
\hline 3 & Agilent 7890/Agilent 5975 MSD & DB-5 & $60 \mathrm{~m} \times 0.25 \mathrm{~mm} \times 0.25 \mu \mathrm{m}$ & on-column & 7 & $0.001-1.0 \mathrm{ng} / \mu \mathrm{L}$ \\
\hline 4 & GC/MS & Restek Rtx-5 & $30 \mathrm{~m} \times 0.25 \mathrm{~mm} \times 0.25 \mu \mathrm{m}$ & split/splitless & 5 & $50-5000 \mathrm{ng} / \mathrm{mL}$ \\
\hline 5 & GC/MS & 5\% Diphenyl, 95\% Dimethy polysiloxane & $30 \mathrm{~m} \times 0.25 \mathrm{~mm} \times 0.25 \mu \mathrm{m}$ & split/splitless & 10 & $2-2000 \mathrm{ng} / \mathrm{mL}$ \\
\hline 6 & Waters Acquity UPLC/FLR/MS/MS & Waters CSH C18 & $0.1 \mathrm{~m} \times 2.1 \mathrm{~mm} \times 1.7 \mu \mathrm{m}$ & NA & 6 & $0.5-500 \mathrm{ng} / \mathrm{mL}$ \\
\hline
\end{tabular}

\begin{tabular}{|c|c|c|c|c|c|c|}
\hline Lab \# & Instrument & Phase & Ikylated PAHs & Mode of injection & $\begin{array}{c}\text { Calibration } \\
\text { curve \# } \\
\text { points }\end{array}$ & Range \\
\hline 1 & GC/MS & Rxi-17sil & $60 \mathrm{~m} \times 0.25 \mathrm{~mm} \times 0.25 \mu \mathrm{m}$ & PTV & 6 & $300 \mathrm{ng} / \mathrm{mL}$ to $0.3 \mathrm{ng} / \mathrm{mL}$ \\
\hline 2 & GC/MS & HP5-MS & $30 \mathrm{~m} \times 0.25 \mathrm{~mm} \times 0.25 \mu \mathrm{m}$ & splitless & 4 & $0.5 \mathrm{ng} / \mathrm{g}$ to $25 \mathrm{ng} / \mathrm{g}$ \\
\hline 3 & Agilent 7890/Agilent 5975 MSD & DB-5 & $60 \mathrm{~m} \times 0.25 \mathrm{~mm} \times 0.25 \mu \mathrm{m}$ & on-column & 7 & $0.001-1.0 \mathrm{ng} / \mu \mathrm{L}$ \\
\hline 4 & GC/MS & Restek Rtx-5 & $30 \mathrm{~m} \times 0.25 \mathrm{~mm} \times 0.25 \mu \mathrm{m}$ & split/splitless & 5 & $50-5000 \mathrm{ng} / \mathrm{mL}$ \\
\hline 5 & GC/MS & 5\% Diphenyl, 95\% Dimethy polysiloxane & $30 \mathrm{~m} \times 0.25 \mathrm{~mm} \times 0.25 \mu \mathrm{m}$ & split/splitless & 10 & $2-2000 \mathrm{ng} / \mathrm{mL}$ \\
\hline 6 & Waters Quattro Micro GC/MS/MS & Restek 5\% diphenyl/ 95\% dimethyl polysiloxane & $31 \mathrm{~m} \times 0.25 \mathrm{~mm} \times 0.25 \mu \mathrm{m}$ & splitless & 5 & $0.5-200 \mathrm{ng} / \mathrm{ml}$ \\
\hline
\end{tabular}

\begin{tabular}{|c|c|c|c|c|c|c|}
\hline Lab \# & Instrument & Phase & droxylated PAHs & Mode of injection & $\begin{array}{c}\text { Calibration } \\
\text { curve \# } \\
\text { points } \\
\end{array}$ & Range \\
\hline 1 & GC/MS & Rxi-17sil & $60 \mathrm{~m} \times 0.25 \mathrm{~mm} \times 0.25 \mu \mathrm{m}$ & PTV & 6 & $188 \mathrm{ng} / \mathrm{mL}$ to $0.2 \mathrm{ng} / \mathrm{mL}$ \\
\hline 2 & $\mathrm{GC} / \mathrm{MS}$ & HP5-MS & $30 \mathrm{~m} \times 0.25 \mathrm{~mm} \times 0.25 \mu \mathrm{m}$ & splitless & 4 & $0.5 \mathrm{ng} / \mathrm{g}$ to $25 \mathrm{ng} / \mathrm{g}$ \\
\hline 6 & Waters Acquity UPLC/FLR/MS/MS & Waters CSH C18 & $0.1 \mathrm{~m} \times 2.1 \mathrm{~mm} \times 1.7 \mu \mathrm{m}$ & NA & 6 & $0.5-500 \mathrm{ng} / \mathrm{mL}$ \\
\hline Lab \# & Instrument & Phase & $\begin{array}{c}\text { DOSS } \\
\text { Dimensions } \\
\end{array}$ & Mode of injection & $\begin{array}{c}\text { Calibration } \\
\text { curve \# } \\
\text { points } \\
\end{array}$ & Range \\
\hline 3 & Waters AcquityUPLC/AB Sciex QTrap 5500 & C 18 & $0.05 \mathrm{~m} \times 2.1 \mathrm{~mm} \times 1.8 \mu \mathrm{m}$ (particle size) & on-column & 6 & $0.5-312.5 \mathrm{ng} / \mathrm{mL}$ \\
\hline 5 & HPLC/MS/MS & $\mathrm{C} 8$ & $150 \mathrm{~mm} \times 3 \mathrm{~mm} \times 3 \mu \mathrm{m}$ (particle size) & NA & 7 & $1-1000 \mathrm{ng} / \mathrm{mL}$ \\
\hline 6 & Waters Acquity UPLC/MS/MS & Waters BEH Shielded RP18 & $0.05 \mathrm{~m} \times 2.1 \mathrm{~mm} \times 1.7 \mu \mathrm{m}$ (particle size) & NA & 6 & $0.5-200 \mathrm{ng} / \mathrm{mL}$ \\
\hline
\end{tabular}


Table B2: Internal standards used for each compound for the analysis of solutions

Lab

\begin{tabular}{|c|c|c|c|c|c|c|}
\hline \multirow[b]{2}{*}{ Compound } & \\
\hline & 1 & 2 & 3 & 4 & 5 & 6 \\
\hline fluorene & naphthalene-d8 & phenanthrene-d10 & acenaphthene-d10 & phenanthrene-d10 & Acenaphthene-d10 & chrysene- $\mathrm{d} 12 /$ naphthalene- $\mathrm{d} 8$ \\
\hline phenanthrene & naphthalene-d8 & phenanthrene-d10 & acenaphthene-d10 & phenanthrene-d10 & phenanthrene-d10 & chrysene-d12/naphthalene- $d 8$ \\
\hline pyrene & pyrene-d10 & fluoranthene-d10 & benzo[a]pyrene-d12 & fluoranthene-d10 & chrysene-d12 & chrysene- $\mathrm{d} 12 /$ naphthalene- $\mathrm{d} 8$ \\
\hline benzo[a]pyrene & benzo[a]pyrene-d12 & benzo[a]pyrene-d12 & benzo[a]pyrene-d12 & benzo[a]pyrene-d12 & perylene-d12 & chrysene- $\mathrm{d} 12 /$ naphthalene- $\mathrm{d} 8$ \\
\hline 1-methylnaphthalene & naphthalene-d8 & & naphthalene-d8 & 2-methylnaphthalene-d10 & NA & chrysene-d12/naphthalene- $d 8$ \\
\hline 2-methylnaphthalene & naphthalene-d8 & naphthalene-d8 & naphthalene-d8 & 2-methylnaphthalene-d10 & naphthalene-d8 & chrysene-d12/naphthalene- $d 8$ \\
\hline 2,6-dimethylnaphthalene & naphthalene-d8 & naphthalene-d8 & acenaphthene-d10 & 2,6-dimethylnaphthalene-d12 & naphthalene-d8 & chrysene- $\mathrm{d} 12 /$ naphthalene- $\mathrm{d} 8$ \\
\hline 1,7-dimethylphenanthrene & phenanthrene-d10 & phenanthrene-d10 & acenaphthene-d10 & fluoranthene-d10 & NA & chrysene-d12/naphthalene- $d 8$ \\
\hline 9-methylphenanthrene & phenanthrene-d10 & phenanthrene-d10 & acenaphthene-d10* & phenanthrene-d10 & phenanthrene-d10 & chrysene- $\mathrm{d} 12 /$ naphthalene- $\mathrm{d} 8$ \\
\hline 3-methylphenanthrene & phenanthrene-d10 & phenanthrene-d10 & acenaphthene-d10 & phenanthrene-d10 & phenanthrene-d10 & chrysene-d12/naphthalene- $\mathrm{d} 8$ \\
\hline 1-naphthol & ${ }^{13} \mathrm{C}$ pentachlorophenol & naphthol-d7 & & & & chrysene-d12/naphthalene-d8 \\
\hline 2,3-dihydroxynaphthalene & ${ }^{13} \mathrm{C}$ pentachlorophenol & naphthol-d7 & & & & chrysene- $\mathrm{d} 12 /$ naphthalene- $\mathrm{d} 8$ \\
\hline 2-methyl-1-naphthol & ${ }^{13} \mathrm{C}$ pentachlorophenol & naphthol-d7 & & & & chrysene-d12/naphthalene-d8 \\
\hline 2-hydroxyfluorene & ${ }^{13} \mathrm{C} 6$-hydroxy chrysene & naphthol-d7 & & & & chrysene-d12/naphthalene-d8 \\
\hline 1-hydroxypyrene & ${ }^{13} \mathrm{C} 6$-hydroxy chrysene & naphthol-d7 & & & & chrysene-d12/naphthalene- $d 8$ \\
\hline \multirow[t]{2}{*}{ Doss } & & & DOSS-d34 & & DOSS-d34 & SDS-d25/SDS-d1 \\
\hline & & & $\begin{array}{l}\text { *the response factor for } \\
\text { 1-methylphenanthrene } \\
\text { was used to quantify 9- } \\
\text { methyl phenanthrene }\end{array}$ & & & \\
\hline
\end{tabular}


Table B3: Methods used for the analysis of QA11Plasma and QA11WholeBlood

\begin{tabular}{|c|c|c|c|c|c|c|c|}
\hline Lab \# & Reported & $\begin{array}{c}\text { g extracted } \\
\text { QA11Plasama }\end{array}$ & $\begin{array}{c}\text { g extracted } \\
\text { QA11WhloeBlood }\end{array}$ & $\begin{array}{l}\text { Extraction } \\
\text { Method }\end{array}$ & Extraction Solvent & Extraction Time & Extraction Other \\
\hline 1 & $12 / 1 / 2011$ & 4 & 4 & $\begin{array}{l}\text { Focused } \\
\text { Microwave } \\
\text { Extraction }\end{array}$ & $\begin{array}{l}5 \mathrm{~mL} \text { sample }+5 \mathrm{~mL} \\
\text { formic acid }+6 \mathrm{~mL} 20 \% \\
\text { dichloromethane:hexane } \\
(\mathrm{V}: \mathrm{V}) \text {, repeat once }\end{array}$ & $\begin{array}{l}250 \mathrm{~W}, 10 \text { min } \\
\text { ramp, } 3 \text { min hold, } \\
90^{\circ} \mathrm{C} \text {, max } \\
\text { pressure was } 1.72 \\
\text { MPa with stirring } \\
\text { and PowerMax on }\end{array}$ & \\
\hline 2 & $12 / 5 / 2011$ & 4 & 4 & Liquid:liquid & $\begin{array}{l}\text { Hexane:MTBE (1:1) 1st } \\
\text { time followed by } \\
\text { hexane:toluene (1:1) } \\
\text { twice }\end{array}$ & $\begin{array}{l}\text { overnight in } \\
\text { refrigerator for } 1 \mathrm{st} \\
\text { solvent; then } 10 \text { to } \\
15 \text { min for other } 2 \\
\text { solvent mixes }\end{array}$ & $\begin{array}{l}\text { formic acid added } \\
\text { just prior to first } \\
\text { solvent addition }\end{array}$ \\
\hline 3 & $11 / 28 / 2011$ & 2 & 2 & $\begin{array}{l}\text { PAHs - ASE; } \\
\text { DOSS - } \\
\text { QuEChERs }\end{array}$ & $\begin{array}{l}\text { PAHs - methylene } \\
\text { chloride; DOSS - } \\
\text { acetonitrile }\end{array}$ & $\begin{array}{l}\text { PAHs - } 24 \min @ \\
2000 \text { psi and } 100 \\
\text { deg C; DOSS - n/a }\end{array}$ & \\
\hline 4 & $12 / 12 / 2011$ & 4 & 4 & $\begin{array}{l}\text { liquid-liquid } \\
\text { extraction }\end{array}$ & Hexane & 30 minutes. & \\
\hline 5 & $11 / 28 / 2011$ & $\begin{array}{l}1 \text { for PAH } 0.1 \\
\text { for DOSS }\end{array}$ & $\begin{array}{c}1 \text { for PAH } 0.1 \text { for } \\
\text { DOSS }\end{array}$ & Solvent partition & $\begin{array}{l}\text { Acetonitrile for DOSS, } \\
\text { Hexane for PAH }\end{array}$ & $1 \mathrm{~min}$ & \\
\hline 6 & 12/12/2011 & 0.5 and 1.0 & 0.5 and 1.0 & QuEChERS/LLE & Acetonitrile/Hexane & $40 \mathrm{~min}$ & \\
\hline
\end{tabular}


Table B4: Methods used for the analysis of QA11Plasma and QA11WholeBlood

\begin{tabular}{|c|c|c|c|c|c|}
\hline \multirow[b]{2}{*}{ Lab\# } & \multirow[b]{2}{*}{ Sample extract cleanup method } & \multicolumn{4}{|c|}{ Method used for quantification } \\
\hline & & $\mathrm{PAH}$ & Alkyl PAH & Hydroxylated PAH & DOSS \\
\hline 1 & Size exclusion chromatography (PIGel $300 \mathrm{~mm} \times 7.5 \mathrm{~mm}$ ) followed by alumina SPE & IS & IS & NA & NA \\
\hline 2 & none & IS & IS & IS & \\
\hline 3 & PAHs - silica/alumina columns and HPLC-SEC; DOSS - none & IS & IS & & IS \\
\hline 4 & Chromatographic clean-up using Biobead, $5 \%$ Silica and $2 \%$ Alumina columns & IS & IS & & \\
\hline 5 & None & IS & IS & & Isotope Dilution \\
\hline 6 & N/A & IS & IS & IS & IS \\
\hline
\end{tabular}


Table B5: Methods used for the analysis of QA11Plasma and QA11WholeBlood

\begin{tabular}{|c|c|c|c|c|c|c|}
\hline $\begin{array}{c}\text { Lab } \\
\#\end{array}$ & Instrument & Phase & Dimensions & $\begin{array}{l}\text { Mode of } \\
\text { injection }\end{array}$ & $\begin{array}{c}\text { Calibration curve \# } \\
\text { points }\end{array}$ & Range \\
\hline 1 & GC/MS & Rxi-17sil & $60 \mathrm{~m} \times 0.25 \mathrm{~mm} \times 0.25 \mu \mathrm{m}$ & PTV & 6 & $\begin{array}{l}1600 \mathrm{ng} / \mathrm{mL} \text { to } 0.32 \\
\mathrm{ng} / \mathrm{mL}\end{array}$ \\
\hline 2 & GC/MS & HP5-MS & $30 \mathrm{~m} \times 0.25 \mathrm{~mm} \times 0.25 \mu \mathrm{m}$ & splitless & 4 & $0.5 \mathrm{ng} / \mathrm{g}$ to $160 \mathrm{ng} / \mathrm{g}$ \\
\hline 3 & Agilent 7890/Agilent $5975 \mathrm{MSD}$ & DB-5 & $60 \mathrm{~m} \times 0.25 \mathrm{~mm} \times 0.25 \mu \mathrm{m}$ & on-col $\mu \mathrm{mn}$ & 7 & $0.001-1.0 \mathrm{ng} / \mathrm{\mu L}$ \\
\hline 4 & GC/MS & Restek Rtx-5 & $30 \mathrm{~m} \times 0.25 \mathrm{~mm} \times 0.25 \mu \mathrm{m}$ & split/splitless & 5 & $50-5000 \mathrm{ng} / \mathrm{mL}$ \\
\hline 5 & GC/MS & $5 \%$ Diphenyl, 95\% Dimethy polysiloxane & $30 \mathrm{~m} \times 0.25 \mathrm{~mm} \times 0.25 \mu \mathrm{m}$ & split/splitless & 10 & $2-2000 \mathrm{ng} / \mathrm{mL}$ \\
\hline 6 & Waters Acquity UPLC/FLR/MS/MS & Waters CSH C18 & $0.1 \mathrm{~m} \times 2.1 \mathrm{~mm} \times 1.7 \mu \mathrm{m}$ & NA & 6 & $0.5-500 \mathrm{ng} / \mathrm{mL}$ \\
\hline $\begin{array}{c}\text { Lab } \\
\#\end{array}$ & Instrument & Phase & $\begin{array}{l}\text { Alkylated PAHs } \\
\text { Dimensions }\end{array}$ & $\begin{array}{l}\text { Mode of } \\
\text { injection }\end{array}$ & $\begin{array}{l}\text { Calibration curve \# } \\
\text { points }\end{array}$ & Range \\
\hline 1 & GC/MS & Rxi-17sil & $60 \mathrm{~m} \times 0.25 \mathrm{~mm} \times 0.25 \mu \mathrm{m}$ & PTV & 6 & $\begin{array}{l}300 \mathrm{ng} / \mathrm{mL} \text { to } 0.3 \\
\mathrm{ng} / \mathrm{mL}\end{array}$ \\
\hline 2 & GC/MS & HP5-MS & $30 \mathrm{~m} \times 0.25 \mathrm{~mm} \times 0.25 \mu \mathrm{m}$ & splitless & 4 & $0.5 \mathrm{ng} / \mathrm{g}$ to $25 \mathrm{ng} / \mathrm{g}$ \\
\hline 3 & Agilent 7890/Agilent 5975 MSD & DB-5 & $60 \mathrm{~m} \times 0.25 \mathrm{~mm} \times 0.25 \mu \mathrm{m}$ & on-column & 7 & $0.001-1.0 \mathrm{ng} / \mu \mathrm{L}$ \\
\hline 4 & GC/MS & Restek Rtx-5 & $30 \mathrm{~m} \times 0.25 \mathrm{~mm} \times 0.25 \mu \mathrm{m}$ & split/splitless & 5 & $50-5000 \mathrm{ng} / \mathrm{mL}$ \\
\hline $\begin{array}{l}5 \\
6\end{array}$ & $\begin{array}{l}\text { GC/MS } \\
\text { Waters Quattro Micro GC/MS/MS }\end{array}$ & $\begin{array}{l}5 \% \text { Diphenyl, 95\% Dimethy polysiloxane } \\
\text { Restek } 5 \% \text { diphenyl/ 95\% dimethyl } \\
\text { polysiloxane }\end{array}$ & $\begin{array}{l}30 \mathrm{~m} \times 0.25 \mathrm{~mm} \times 0.25 \mu \mathrm{m} \\
31 \mathrm{~m} \times 0.25 \mathrm{~mm} \times 0.25 \mu \mathrm{m}\end{array}$ & $\begin{array}{l}\text { split/splitless } \\
\text { splitless }\end{array}$ & $\begin{array}{l}10 \\
5\end{array}$ & $\begin{array}{l}2-2000 \mathrm{ng} / \mathrm{mL} \\
0.5-200 \mathrm{ng} / \mathrm{ml}\end{array}$ \\
\hline $\begin{array}{c}\text { Lab } \\
\#\end{array}$ & Instrument & Phase & $\begin{array}{l}\text { Hydroxylated PAHs } \\
\text { Dimensions }\end{array}$ & $\begin{array}{l}\text { Mode of } \\
\text { injection }\end{array}$ & $\begin{array}{l}\text { Calibration curve \# } \\
\text { points }\end{array}$ & Range \\
\hline 2 & GC/MS & HP5-MS & $30 \mathrm{~m} \times 0.25 \mathrm{~mm} \times 0.25 \mu \mathrm{m}$ & splitless & 4 & $0.5 \mathrm{ng} / \mathrm{g}$ to $25 \mathrm{ng} / \mathrm{g}$ \\
\hline 6 & Waters Acquity UPLC/FLR/MS/MS & Waters $\mathrm{CSH} C 18$ & $0.1 \mathrm{~m} \times 2.1 \mathrm{~mm} \times 1.7 \mu \mathrm{m}$ & NA & 6 & $0.5-500 \mathrm{ng} / \mathrm{mL}$ \\
\hline $\begin{array}{c}\text { Lab } \\
\#\end{array}$ & Instrument & Phase & $\begin{array}{l}\text { Doss } \\
\text { Dimensions }\end{array}$ & $\begin{array}{l}\text { Mode of } \\
\text { injection }\end{array}$ & $\begin{array}{l}\text { Calibration curve \# } \\
\text { points }\end{array}$ & Range \\
\hline 3 & $\begin{array}{l}\text { Waters AcquityUPLC/AB Sciex QTrap } \\
5500\end{array}$ & C 18 & $\begin{array}{l}0.05 \mathrm{~m} \times 2.1 \mathrm{~mm} \times 1.8 \mu \mathrm{m} \text { (particle } \\
\text { size) } \\
150 \mathrm{~mm} \times 3 \mathrm{~mm} \times 3 \mu \mathrm{m} \text { (particle }\end{array}$ & on column & 6 & $0.5-312.5 \mathrm{ng} / \mathrm{mL}$ \\
\hline 5 & $\mathrm{HPLC} / \mathrm{MS} / \mathrm{MS}$ & & $\begin{array}{l}\text { size) } \\
0.05 \mathrm{~m} \times 2.1 \mathrm{~mm} \times 1.7 \mu \mathrm{m} \text { (particle }\end{array}$ & NA & 7 & $1-1000 \mathrm{ng} / \mathrm{mL}$ \\
\hline 6 & Waters Acquity UPLC/MS/MS & Waters BEH Shielded RP18 & size) & NA & 6 & $0.5-200 \mathrm{ng} / \mathrm{mL}$ \\
\hline
\end{tabular}


Table B6: Methods used for the analysis of QA11Plasma and QA11WholeBlood

\begin{tabular}{|c|c|c|c|c|}
\hline \multirow[b]{2}{*}{ Lab \# } & \multirow[b]{2}{*}{ IS/surrogate added prior to extraction } & \multicolumn{3}{|l|}{ PAHs } \\
\hline & & Used? & Added prior to analysis & Used? \\
\hline 1 & napthalane-d8; pyrene-d10; benzo[a]pyrene-d12; phenanthrene-d10 & \multicolumn{3}{|l|}{ Yes } \\
\hline 2 & naphthalene-d8; phenanthrene-d10; fluoranthene-d10; B[a]P-d12 & \multicolumn{3}{|l|}{ Yes } \\
\hline 3 & naphthalene-d8, acenaphthene-d10, Benzo[a]pyrene-d12 & Yes & phenanthrene-d10; prior to cleanup & $*$ \\
\hline 4 & $\begin{array}{l}\text { phenanthrene-d10; fluoranthene-d10, benzo(a)pyrene-d12, 2-methylnaphthalene-d10 and } \\
\text { 2,6-Dimethylnaphthalene-d12 }\end{array}$ & Yes & \multicolumn{2}{|l|}{$\begin{array}{l}\text { acenaphthene-d10, pyrene-d10 and } \\
\text { benzo(e)pyrene-d12 }\end{array}$} \\
\hline 5 & fluorene-d10, fluoranthene-d10, terphenyl-d14 & yes & $\begin{array}{l}\text { naphthalene-d8, acenaphthene-d10, } \\
\text { phenanthrene-d10, chrysene-d12, perylene-d12 }\end{array}$ & yes \\
\hline \multirow[t]{2}{*}{6} & naphthalene-d8 & Yes & chrysene-d12 & Yes \\
\hline & & \multicolumn{3}{|c|}{ Alkylated PAHs } \\
\hline Lab \# & IS/surrogate added prior to extraction & Used? & Added prior to analysis & Used? \\
\hline 1 & napthalane-d8; pyrene-d10; benzo[a]pyrene-d12; phenanthrene-d10 & \multicolumn{3}{|l|}{ Yes } \\
\hline 2 & naphthalene-d8; phenanthrene-d10; fluoranthene-d10; B[a]P-d12 & \multicolumn{3}{|l|}{ Yes } \\
\hline 3 & naphthalene- $d 8$, acenaphthene- $d 10$, benzo[a]pyrene- $d 12$ & Yes & phenanthrene-d10; prior to cleanup & $*$ \\
\hline 4 & $\begin{array}{l}\text { phenanthrene-d10; fluoranthene-d10, benzo[a]pyrene-d12, 2-methylnaphthalene-d10 and } \\
\text { 2,6-dimethylnaphthalene-d12 }\end{array}$ & Yes & \multicolumn{2}{|l|}{$\begin{array}{l}\text { d10-acenaphthene, d10-pyrene and d12- } \\
\text { benzo(e)pyrene }\end{array}$} \\
\hline 5 & fluorene-d10, fluoranthene-d10, terphenyl-d14 & yes & $\begin{array}{l}\text { naphthalene-d8, acenaphthene-d10, } \\
\text { phenanthrene-d10, chrysene-d12, perylene-d12 }\end{array}$ & yes \\
\hline \multirow[t]{2}{*}{6} & naphthalene-d8 & Yes & chrysene-d12 & yes \\
\hline & & \multicolumn{3}{|c|}{ Hydroxylated PAHs } \\
\hline Lab \# & IS/surrogate added prior to extraction & Used? & Added prior to analysis & Used? \\
\hline 2 & naphthol-d7 & Yes & & \\
\hline \multirow[t]{2}{*}{6} & naphthalene- $d 8$ & & \multicolumn{2}{|l|}{ chrysene-d12 } \\
\hline & & \multicolumn{3}{|l|}{ DOSS } \\
\hline Lab \# & IS/surrogate added prior to extraction & Used? & Added prior to analysis & Used? \\
\hline 3 & DOSS-d34 & Yes & Sodium dodecyl sulfate-d25 & $*$ \\
\hline 5 & DOSS-d34 & Yes & DOSS-C13 & Yes \\
\hline \multirow[t]{2}{*}{6} & Sodium dodecyl sulfate-d1 (SDS-d1) & \multirow[t]{2}{*}{ Yes } & \multirow[t]{2}{*}{ Sodium dodecyl sulfate-d25 (SDS-d25) } & \multirow[t]{2}{*}{ Yes } \\
\hline & ${ }^{*}$ used to calculate surrogate recovery & & & \\
\hline
\end{tabular}


Table B7: Internal standards used for each compound for the analysis of QA11Plasma and QA11WholeBlood

Lab

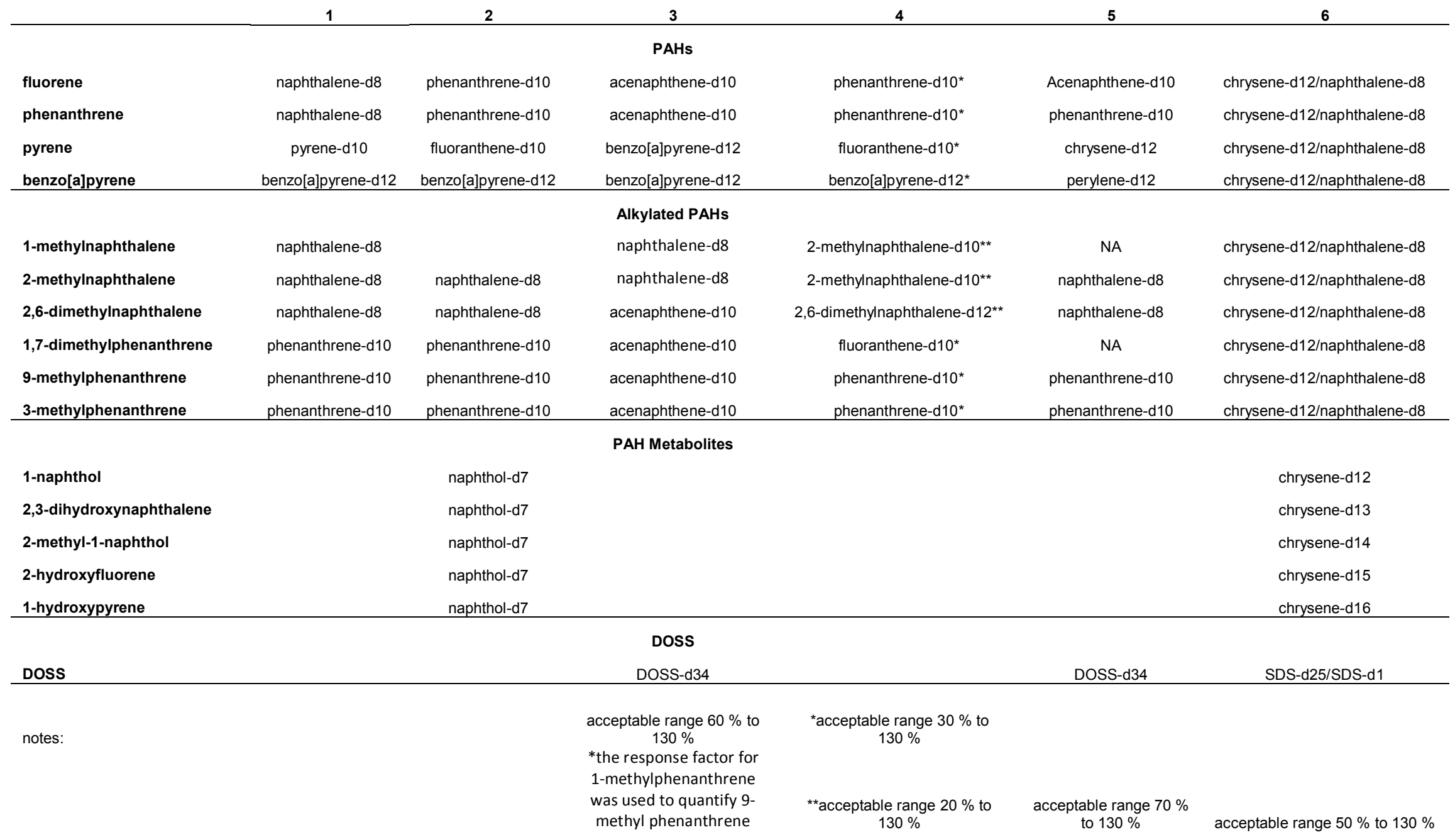


Appendix C: Participating Laboratories 


\section{Participating Laboratories}

Axys Analytical Services Ltd., Sidney, BC Canada

Columbia Analytical Services Inc., Kelso, WA USA

National Institute of Standards and Technology, Charleston, SC USA

National Institute of Standards and Technology, Gaithersburg, MD USA

National Oceanic and Atmospheric Administration, Northwest Fisheries Science Center, Seattle, WA USA

University of Connecticut, Center for Environmental Sciences and Engineering, Storrs, CT USA 